\title{
Synthesis and Characterization of Some New Nucleoside Analogues from Substituted Benzimidazole via 1,3-Dipolar cycloaddition
}

Thanaa M. Al-Mouamin*

*Department of Chemistry, College of Science, Baghdad University, Baghdad, Iraq.

Ministry of Environment, Baghdad, Iraq.

E-mail: ahmed_khudair@yahoo.com

Received 19/9/2015

Accepted 20/12/2015

\section{(1) 9}

EY No ND This work is licensed under a Creative Commons Attribution-NonCommercialNoDerivatives 4.0 International Licens

\section{Abstract}

This paper includes the synthesis of some new nucleoside analogues starting with 2-substituted benzimidazole derivative (7-9), that synthesized by condensation of O-phenylenediamine with p-chloro benzaldehyde and two substituted benzoic acid , which on nucleophilic substitution with propargyl bromide gave a new $\mathrm{N}$ substituted compounds (10-12). D-Fructose and D-galactose were chosen as a sugar moiety which were protected, brominated and azotated to give azido sugars (5) and (6), then they were subjected to 1,3-dipolar cycloaddition reaction with $\mathrm{N}$-substuted compounds afforded bloked nucleoside analoges (13-16), which after hydrolysis gave our target the free nucleoside analogues (17-20).

All prepared compounds were identified by FT-IR and some of them with ${ }^{1} \mathrm{H}-\mathrm{NMR}$ and ${ }^{13} \mathrm{C}-\mathrm{NMR}$.

Key words: Nucleoside analogues, Benzimidazole, Trizole.

\section{Introduction:}

In recent years Nucleoside analogues played pivotal roles in the treatment of viral infections and cancer, nucleosides are active ingredient of one third of the antiviral drugs approved by the US food and drug administration (FDA)[1], thus considered one of the great importance among the compounds with antiviral activity; therefore, to modulate nucleoside or nucleotide activity, the strategy has been modified one of the three major subunit moiety[2]. Nucleoside analogues such as Favipiravir, has demonstrated success in treating Ebola virus infections in both cell culture and small animal models $[3,4]$.

Benzimidazole is heterocyclic aromatic organic compound. This bicyclic compound consists of the fusion of benzene and imidazole[5].

The most prominent benzimidazole compounds in nature is $N$-ribosyldimethylbenzimidazole, which serves as an axial ligand for cobalt in vitamin $\mathrm{B}_{12}$, On the other hand, benzimidazole is an important pharmacophore due to the structural similarty of purine[6].

New antiviral drugs and in last year's several biological application like anti- 
microbial[7], antiviral especially HIV virus[8], antiprotozoal[9], antiinflammatory[10], anthelmintic[11], antihypertensive[12], anti-tumor[13] and anticonvulsant activities[14] and CNSdepressant[15], have been reported for benzimidazole derivatives[16].

\section{Materials and Methods:- Instruments}

- Melting points were recorded by Gallen Kamp , England .Melting point apparatus were uncorrected,.

- Infrared spectra were recorded using Fourier Transform infrared SHIMADZU (8300) (FTIR) infrared spectrometer, Japan,as $\mathrm{KBr}$ disc or thin film .

- ${ }^{1} \mathrm{H}-\mathrm{NMR}$ and ${ }^{13} \mathrm{C}-\mathrm{NMR}$ spectra were recorded on Burker, Ultra shield $300 \mathrm{MHz}$, Jordan, Amman, using tetramethyl silane as internal standard and DMSO- $\mathrm{d}_{6}$ as a solvent.

- Biological activity using incubator Memmert.

- The DMSO- $\mathrm{d}_{6}$ solvent appeared at $2.5 \mathrm{ppm}$ in ${ }^{1} \mathrm{H}-\mathrm{NMR}$ and at $40.45 \mathrm{ppm}$ in ${ }^{13} \mathrm{C}-\mathrm{NMR}$ spectrum[12]

\section{Chemicals}

- All chemical starting compounds were obtained from Fluka, Aldrich and BDH

\section{General procedure}

Synthesis of $1,3,4,6$ - tetra -O-benzoyl - $\beta$-D- fructofuranose

Benzoyl chloride ( $14 \mathrm{ml}$ ) was added to anhydrous -D- fructose ( $4 \mathrm{~g}, 22.22$ mmol) that suspended in a mixture of chloroform $(60 \mathrm{ml})$ and dry pyridine $(10$ $\mathrm{ml})$, Then the mixture was heated on water bath at ( $45-65)^{\circ} \mathrm{C}$ with continuous stirring for 4 hs.

The mixture was poured over ice -water then extracted with $\mathrm{CHCl}_{3}(3 \times 15 \mathrm{ml})$. Then washed organic phase with $(20 \mathrm{ml})$ $(5 \% \mathrm{HCl})$ solution and neutralized with $\left(5 \% \quad \mathrm{Na}_{2} \mathrm{CO}_{3}\right)$ solution $(20 \mathrm{ml})$, the organic phase dried over anhydrous sodium sulphate and the solvent evaporated to give a syrup.
Synthesis of 1,3,4,6- Tetra- O-benzoyl - $\beta$ - D- fructofuranosyl bromide

Added Hydrogen bromide in glacial acetic acid (5 $\mathrm{ml})$ of $(45 \%)$ to tetrabenzoyl fructofuranose $(2 \mathrm{~g}, 3.36$ mmol ) then added $(5 \mathrm{ml})$ of glacial acetic acid. The mixture was stirred for $30 \mathrm{mins}$ ) and left for 6 hs., then the mixture was left over night at $\left(5{ }^{\circ} \mathrm{C}\right)$ after that the mixture was neutralized with saturated aqueous sodium bicarbonate solution and extracted with chloroform $(3 \times 15 \mathrm{ml})$, dried over anhydrous sodium sulphate, filtered, evaporated in vacuo to give a brown syrup .

\section{1,2:3,4-Di-O-isopropylidene- $\alpha$ - D- galactopyranose}

Anhydrous zinc chloride (9.5 g) was dissolved in $100 \mathrm{ml}$ of acetone with stirring until the zinc chloride was dissolved. Concentrated sulfuric acid $(0.32 \mathrm{ml})$ was rapidly added drop-wise ,finely powdered, anhydrous Dgalactose ( $9 \mathrm{~g}, 0.05$ mole ) was quickly added and the mixture was stirred magnetically for $4 \mathrm{hs}$. A suspension of (16 g) of anhydrous sodium carbonate in $(28 \mathrm{ml})$ of water was added in portions and the mixture was stirred. The suspension was filtered, and the precipitate was washed several times with acetone and filtered. The filtrate and washings are combined, and the solution was evaporated under vacuo. The mixture was extracted 3 times with ether, dried with anhydrous sodium sulfate, filtered, and evaporated to dryness under vacuo to give product (4) as pale yellow syrup.

\section{1,2:3,4-Di-O-isopropylidene- $\alpha$ - D- galactopyranosyl bromide}

Hydrogen bromide in glacial acetic acid $(5 \mathrm{ml})$ of $(45 \%)$ was added to 1,2:3,4-di-O-isopropylidene- $\alpha$ - $\quad D$ galactopyranose (4) (4 g, 12.38mmol) then $(5 \mathrm{ml})$ of glacial acetic acid was added. The mixture was stirred for 30 min. at room temperature and then left for $6 \mathrm{hs}$. at room temperature. The 
mixture left over night at $\left(5^{\circ} \mathrm{C}\right)$ then the mixture was neutralized with saturated aqueous sodium bicarbonate solution and extracted with chloroform (3x $15 \mathrm{ml}$ ), dried with anhydrous sodium sulphate, filtered and evaporated in vacuo to give a brown syrup .

Synthesis of 1,3,4,6- Tetra- O-benzoyl -2 - azido-2- deoxy- $\beta$ - Dfructofuranose and 1,2:3,4-Di-Oisopropylidene-6-azido-5-deoxy- $\alpha$-Dgalactopyranose

Excess of sodium azide was added to [5] sugar bromide (4g, .14.03 $\mathrm{mmol}$ ) in $20 \mathrm{ml}$ DMF. The mixture was heated with stirring at $(50-60)^{\circ} \mathrm{C}$ for $20 \mathrm{hs}$. The mixture was poured on to ice-cold water and extracted with chloroform $(3 \times 15 \mathrm{ml})$, dried with anhydrous sodium sulphate, filtered, evaporated in vacuo to give the compound $(3,6)$ as a brown syrup .

General procedure for the synthesis of 2- substituted phenyl benzimidazole [17]

$(0.078 \mathrm{~g}, 0.6 \mathrm{mmol})$ of $\mathrm{NaHSO}_{3}$ was added to a mixture of $(2.16 \mathrm{~g}, 20 \mathrm{mmol})$ of O-phenylene diamine and ( $20 \mathrm{mmol}$ ) of substituted aromatic aldehyde in (10 $\mathrm{ml}$ ) of DMF then heated with stirring at $80^{\circ} \mathrm{C}$ for $4 \mathrm{~h}$., distilled water $(40 \mathrm{ml})$ was added to the above mixture and then filtered, recrystallization was achieved by using $30 \% \mathrm{ml}$ ethanol.

General procedure for the preparation of 1-propynyl - 2substituted phenyl benzimidazole

Prepared benzimidazole derivative $(10$ mmol) was heated under refluxe with alcoholic potassium hydroxide $(4 \mathrm{M})$ for $0.5 \mathrm{hrs}$. then $(0.88 \mathrm{ml}, 10 \mathrm{mmol})$ of propargyl bromide was added and was heated under reflux in boiling water bath for 3-4 hrs. , filtered and recrystallized from ethyl acetate.

General procedure for the preparation of nucleoside analogues 1-propynyl - 2-substiuted phenyl benzimidazole $(20 \mathrm{mmol})$ was added to sugar azide (20 mmol ) with $\mathrm{Cu}^{\mathrm{I}}(0.016$ $\mathrm{mmol}$ ) in base medium then stirred for $72 \mathrm{hrs}$. at room temperature.

\section{Hydrolysis of nucleoside analogues}

A solution of ( $0.3 \mathrm{~g})$ of the blocked nucleoside in $(14 \mathrm{ml})$ of $(0.1 \mathrm{M})$ methanolic sodium methoxide was refluxed with stirring for $0.5 \mathrm{~h}$., neutralized with acetic acid and evaporated to dryness. The residue was partitioned between water and chloroform and the aqueous phase evaporated to dryness in vacuo, then was recrystallized from ethanol ether .

\section{Results and Discussion}

Structurally modified nucleosides represent an important class of medicinal compounds which have been found to behave as therapeutic agents and are currently used in pharmaceuticals as antitumor, antiviral and antibiotic agent.( 16)

Physical properties of sugars compounds (2-6) were agreed with that in the literature

The FT-IR spectrum for compound (2) showed stretching band at $3064 \mathrm{~cm}^{-1}(\mathrm{C}$ $\mathrm{H}$ arom.), $2929 \mathrm{~cm}^{-1}(\mathrm{C}-\mathrm{H}$ aliph.), a stretching band at $1710 \mathrm{~cm}^{-1}(\mathrm{C}=\mathrm{O}$ benzoate $), 1573 \mathrm{~cm}^{-1}(\mathrm{C}=\mathrm{C})$ arom., and $659.61 \mathrm{~cm}^{-1}(\mathrm{C}-\mathrm{Br})$, while a stretching broad band of the hydroxyl group was disappeared(Table 1) .

The FT-IR spectrum of the azido sugar (3) showed stretching bands at $3072 \mathrm{~cm}^{-1}$ (C-H arom), $2931 \mathrm{~cm}^{-1}(\mathrm{C}-\mathrm{H}$ aliph.), a stretching band at $1722 \mathrm{~cm}^{-}$ ${ }^{1}\left(\mathrm{C}=\mathrm{O}\right.$ benzoate), $1496.66 \mathrm{~cm}^{-}$ ${ }^{1}(\mathrm{C}=\mathrm{C})$ arom., $\quad 2123 \mathrm{~cm}^{-1}\left(\mathrm{~N}_{3}\right)$ appeared while the stretching band for $\mathrm{C}-\mathrm{Br}$ was disappeared .

The FT-IR spectrum of galactose isopropylidene showed a stretching band of (C-O-C) at $1255.57 \mathrm{~cm}^{-1}$ appeared for protected group isopropylidene while compound (5) showed in addition of stretching band of (C-O-C) at $1273 \mathrm{~cm}^{-1}$ another strectching band in $648.8 \mathrm{~cm}^{-1}$ for $(\mathrm{C}-\mathrm{Br})$ bond while the stretching 
band for $(\mathrm{OH})$ at $3433 \mathrm{~cm}^{-1}$ was disappeared. Compound (6) spectrum showed a stretching band at $1232 \mathrm{~cm}^{-1}$ for (C-O-C), a stretching band at 2970 $\mathrm{cm}^{-1}\left(\mathrm{C}-\mathrm{H}\right.$ aliph.) and $2129 \mathrm{~cm}^{-1}$ for azide.

Table (1): FT-IR spectral data $\mathrm{cm}^{-1}$ for compounds (1-6)

\begin{tabular}{|c|c|c|c|c|c|c|}
\hline No. & $\begin{array}{c}\mathrm{C}- \\
\mathrm{H}_{\text {aliph. }}\end{array}$ & $\begin{array}{c}\mathrm{C}-\mathrm{H} \\
\text { arom }\end{array}$ & $\mathrm{C}=\mathrm{C}_{\text {arom. }}$ & $\mathrm{C}=\mathrm{O}$ & $\mathrm{C}-\mathrm{O}-\mathrm{C}$ & Other \\
\hline 1 & 2916 & 3064 & 1583.45 & 1728 & - & $\mathrm{O}-\mathrm{H}(3417)$ \\
\hline 2 & 2929.67 & 3064.68 & 1573.81 & 1710.74 & - & $\mathrm{C}-\mathrm{Br}(659.61)$ \\
\hline 3 & 2931.6 & 3072.39 & 1496.66 & 1722 & - & $\mathrm{N} \equiv \mathrm{N}(2123.48)$ \\
\hline 4 & 2931 & - & - & - & 1255.57 & $\mathrm{O}-\mathrm{H}(3433)$ \\
\hline 5 & 2900 & - & - & - & 1273 & $\mathrm{C}-\mathrm{Br}(648.08)$ \\
\hline 6 & 2970 & - & - & - & 1232 & $\mathrm{~N} \equiv \mathrm{N}(2129.27)$ \\
\hline
\end{tabular}

Benzimidazole was synthesized by condensation of $O$-phenylenediamine with 4-chloro benzaldehyde using sodium hydrogen sulfite as ring closing agent, giving a good yield (70-85\%).or

with 2-toluic or 4-toluic acide when hydrochloric acid was used as a catalyst. Some of physical properties are listed in Table (2).

Table (2): Some of physical properties of compounds (7-9)

\begin{tabular}{|l|l|l|l|c|c|}
\hline Comp. No. & Molecular formula & M.wt $(\mathrm{g} / \mathrm{mol})$ & $\mathrm{m} . \mathrm{p}^{\circ} \mathrm{C}$ & Color \\
\hline 7 & 228 & $260-264$ & 218 \\
yellow \\
\hline 9
\end{tabular}

The FT-IR spectrum of benzimidazole compounds (7-9) showed a stretching band at $3400-3429 \mathrm{~cm}^{-1}$ for secondary amine, stretching band at $1502-1587 \mathrm{~cm}^{-}$
${ }^{1}$ for $(\mathrm{C}=\mathrm{C})$ aromatic, $3060-3068 \mathrm{~cm}^{-1}$ for $(\mathrm{C}-\mathrm{H})$ aromatic, stretching and at 1610$1631 \mathrm{~cm}^{-1}$ for $v(\mathrm{C}=\mathrm{N})$.

Table (3): FT-IR spectral data $\mathrm{cm}^{-1}$ for compounds (7-9)

\begin{tabular}{|c|c|c|c|c|c|c|}
\hline Comp. & $\boldsymbol{v}(\mathbf{N}-\mathbf{H})$ & $\boldsymbol{v}(\mathbf{C}-\mathbf{H})$ aromatic & $\boldsymbol{v}(\mathbf{C}-\mathbf{H})$ aliph. & $\boldsymbol{v}(\mathbf{C}=\mathbf{C})$ aromatic & $v(\mathbf{C}=\mathbf{N})$ & other \\
\hline 7 & 3410 & 3068 & & 1587 & 1610 & \\
\hline 8 & 3429.2 & 3062 & 2920.03 & 1502.44 & 1631 & \\
\hline 9 & 3400 & 3060 & 2829.38 & 1581.52 & 1622 & \\
\hline
\end{tabular}

For ferther modification of nucleobase , substituted benzimidazole (7-9) were undergoing nucleophilic substitution with propargyl bromide to give 1- proynyl -2- substituted benzimidazole derivatives (10-12) .

Some of physical properties are listed in Table (4). 
Table (4): Some of physical properties of compounds (10-12)

\begin{tabular}{|l|c|c|c|c|c|}
\hline Comp. No. & Molecular formula & M.wt $(\mathrm{g} / \mathrm{mol})$ & m.p ${ }^{\circ} \mathrm{C}$ & Color \\
\hline 10 & $\mathrm{C}_{16} \mathrm{H}_{11} \mathrm{~N}_{2} \mathrm{Cl}$ & 266 & yellow \\
\hline 11 & $\mathrm{C}_{17} \mathrm{H}_{14} \mathrm{~N}_{2}$ & $245-278$ & $190-193$ & Brown \\
\hline
\end{tabular}

The FT-IR of compounds(10-12) showed the disappearance of the secondary amine bands. This was demonstrated substitution of propynyl on nitrogen while acetylenic bond showed stretching bands in the range of
2125-2190 $\mathrm{cm}^{-1}$.also showed stretching bands in range between 2815 to 2925 $\mathrm{cm}^{-1}$ for $\mathrm{C}-\mathrm{H}$ aliph. Compound (10) showed a stretching band at 806 for C$\mathrm{Cl}$.

Table (5): FT-IR spectral data $\mathrm{cm}^{-1}$ for compounds (10-12)

\begin{tabular}{|c|c|c|c|c|c|c|c|}
\hline Comp. & $\mathrm{C} \equiv \mathrm{C}$ & $\begin{array}{c}v(\mathrm{C}-\mathrm{H}) \\
\text { aromatic }\end{array}$ & $v(\mathrm{C}-\mathrm{H})$ aliph. & $\begin{array}{c}v(\mathrm{C}=\mathrm{C}) \\
\text { aromatic }\end{array}$ & $v(\mathrm{C}=\mathrm{N})$ & $v(\mathrm{O}-\mathrm{H})$ & other \\
\hline 10 & 2125 & 3074.53 & 2908.65 & 1527.62 & 1604.71 & - & $\mathrm{C}-\mathrm{Cl}(806.25)$ \\
\hline 11 & 2190 & 3062 & 2925 & 1560 & 1625 & - & \\
\hline 12 & 2169.77 & 3049.25 & $2815-2945$ & 1577.66 & 1674.1 & - & \\
\hline
\end{tabular}

The target nucleoside was prepared through 1,3-dipolar cycloaddition reaction by coupling of nucleobase benzimidazole derivative and sugar moiety using $\mathrm{Cu}^{\mathrm{I}}$ as a catalyst to give the blocked nucleoside when 1,2,3trizole were configured. Some of physical properties are listed in Table (6).

Table (6):Some of physical properties of compounds (13-16)

\begin{tabular}{|c|c|c|c|c|c|}
\hline No. & Compound Structure & $\begin{array}{c}\text { Molecular } \\
\text { formula }\end{array}$ & M.wt (g/mol) & m.p & Color \\
\hline 13 & & $\mathrm{C} 50 \mathrm{H} 38 \mathrm{ClN} 5 \mathrm{O} 9$ & 883 & $>172$ & brown \\
\hline 14 & & $\mathrm{C}_{51} \mathrm{H}_{41} \mathrm{~N}_{5} \mathrm{O}_{9}$ & 867 & $>112$ & brown \\
\hline 15 & & $\mathrm{C}_{28} \mathrm{H}_{30} \mathrm{ClN}_{5} \mathrm{O}_{5}$ & 552 & $\begin{array}{l}102- \\
105\end{array}$ & yellow \\
\hline 16 & & $\mathrm{C}_{29} \mathrm{H}_{33} \mathrm{~N}_{5} \mathrm{O}_{5}$ & 531 & $\begin{array}{l}107- \\
109\end{array}$ & green \\
\hline
\end{tabular}


The $2^{\text {nd }}$ National Conference of Chemistry

Table (7): FT-IR spectral data $\mathrm{cm}^{-1}$ for compounds (13-16)

\begin{tabular}{|c|c|c|c|c|c|c|c|}
\hline Comp. & $\begin{array}{c}\boldsymbol{v}(\mathbf{C}-\mathbf{H}) \\
\text { aromatic }\end{array}$ & $\begin{array}{c}\boldsymbol{v}(\mathbf{C}-\mathbf{H}) \\
\mathbf{a l i p h}\end{array}$ & $\begin{array}{c}\boldsymbol{v}(\mathbf{C}=\mathbf{C}) \\
\text { aromatic }\end{array}$ & $\boldsymbol{v}(\mathbf{C}-\mathbf{N})$ & $\boldsymbol{v}(\mathbf{C}=\mathbf{O})$ & $\boldsymbol{v}(\mathbf{C}-\mathbf{O}-\mathbf{C})$ & $\boldsymbol{v}(\mathbf{N}=\mathbf{N})$ \\
\hline 13 & 3062.75 & 2908 & 1590 & 1600 & 1714 & - & 1452.3 \\
\hline 14 & 3060 & 2928 & 1576 & 1602 & 1718 & - & 1422 \\
\hline 15 & 3078 & 2920.23 & 1523.76 & 1608.63 & - & 1203.58 & 1450 \\
\hline 16 & 3068 & 2930 & 1508 & 1620 & - & 1180 & 1440 \\
\hline
\end{tabular}

The ${ }^{1} \mathrm{H}-\mathrm{NMR}$ spectrum of 16 showed a singlet at $1.64 \mathrm{ppm}$ for four isopropyledene protons other singlet appeared at 2.5 for methyl toluene, three sugar protons $\mathrm{H}_{5}{ }_{5}, \mathrm{H}_{6}{ }_{6}, \mathrm{H}^{\prime \prime}{ }_{6}$ appeared at 2.7- $3.7 \mathrm{ppm}$.
The multiplet $4.2-5 \mathrm{ppm}$ refers to $\mathrm{H}_{4}^{\prime}, \mathrm{H}_{3}{ }_{3}, \mathrm{H}_{2}^{\prime}, \mathrm{H}^{\prime}{ }_{1}$ respetivly while the multiplet signal at 8.3-8.7 refered to the aromatic carbons and triazole protons

\section{Table (8): ${ }^{1} \mathrm{H}-\mathrm{NMR}$ spectral data for compound(16)}

\begin{tabular}{|c|c|c|}
\hline Comp.No. & Structures & ${ }^{1} \mathrm{HNMR}$ Spectral data $(\delta \mathrm{ppm})$ \\
\hline 16 & & $\begin{array}{c}\left.\text { 1.64(s, } 12 \mathrm{H}, 4 \mathrm{CH}_{3}, \text { isopropyledene }\right) ; \\
2.50(\mathrm{~s}, 3 \mathrm{H}, \text { methyltoluene }) 2.7-^{\prime} \\
3.7\left(3 \mathrm{H}, \mathrm{H}_{5}{ }_{5}, \mathrm{H}_{6}{ }_{6}, \mathrm{H}^{\prime \prime}{ }_{6}\right) ; 4.2- \\
5\left(\mathrm{~m}, 4 \mathrm{H}, \mathrm{H}_{4}^{\prime}, \mathrm{H}_{3}{ }_{3}, \mathrm{H}_{2}{ }_{2}, \mathrm{H}^{\prime}{ }_{1} \text { and }\right. \\
\text { methylene }) ; 8.3-8.7(\mathrm{~m}, 9 \mathrm{H}, \mathrm{Ar}-\mathrm{H} \\
\text { and triazole proton })\end{array}$ \\
\hline
\end{tabular}

The ${ }^{13} \mathrm{C}$-NMR spectrum of compound 16 showed a signal at 24.6 ppm referred to methyl in toluene and a signal at 38.292 refers to four methyl isopropylidene, a signal at 44.19 refers to methylene, sugar carbons appeared at (61.92, 62.9,68,69,75and 89) ppm refers to $\left(\mathrm{C}_{6}^{\prime}, \quad \mathrm{C}_{5}^{\prime}, \quad \mathrm{C}_{2}^{\prime}, \quad \mathrm{C}_{3}^{\prime}, \quad \mathrm{C}_{4}^{\prime}, \quad \mathrm{C}_{1}^{\prime}\right)$ respectively, a signal $(110,112) \mathrm{ppm}$ for two isopropylidene carbons, aromatic carbons appeared a signal at 116-125 ppm , two carbons of triazole appeared at $126,142 \mathrm{ppm}$, while carbon of imidazole appeared at $156.87 \mathrm{ppm}$.

Table $(9):{ }^{13} \mathrm{C}$-NMR spectral data for compound (16)

\begin{tabular}{|c|c|c|}
\hline Comp. No. & Structures & ${ }^{13} \mathrm{C}-\mathrm{NMR}$ spectral data $(\delta \mathrm{ppm})$ \\
\hline 16 & & $\begin{array}{c}24.6\left(1 \mathrm{C}, \mathrm{CH}_{3}\right) ; 38.292\left(4 \mathrm{C}, 4 \mathrm{CH}_{3}\right. \\
\text { toluene }) ; 44.19\left(1 \mathrm{C}, \mathrm{CH}_{2}, \text { methylene }\right) ; \\
61.92\left(1 \mathrm{C}, \mathrm{C}_{6}^{\prime}\right) ; 62.9\left(1 \mathrm{C}, \mathrm{C}_{5}^{\prime}\right) ; 68\left(1 \mathrm{C}, \mathrm{C}_{2}^{\prime}\right) ; \\
69\left(1 \mathrm{C}, \mathrm{C}_{3}^{\prime}\right) ; 75\left(1 \mathrm{C}, \mathrm{C}_{4}^{\prime}\right) ; 89\left(1 \mathrm{C}, \mathrm{C}_{1}^{\prime}\right) ; \\
110,112(2 \mathrm{C}, 2 \text { isopropyledene }) ; 116- \\
125(12 \mathrm{C}, \text { aromatic }) ; 126,142(2 \mathrm{C}, \\
\text { triazole }) ; 156.87(1 \mathrm{C}, \text { imidazole })\end{array}$ \\
\hline
\end{tabular}

To achieve our synthetic target the nucleoside analogues, the bloked nucleoside (23-29) were debloked in fructose moiety the benzoate ester were hydrolyzed using methanolic sodium methoxide afforded our synthetic goal
The isopropylidene protecting group in galactosemoiety [30,31] were hydrolyzed using 50\%aqueose acetic acid afforded our target of the free nucleoside analogues 
Table (10): Physical properties of compounds ([17-20)

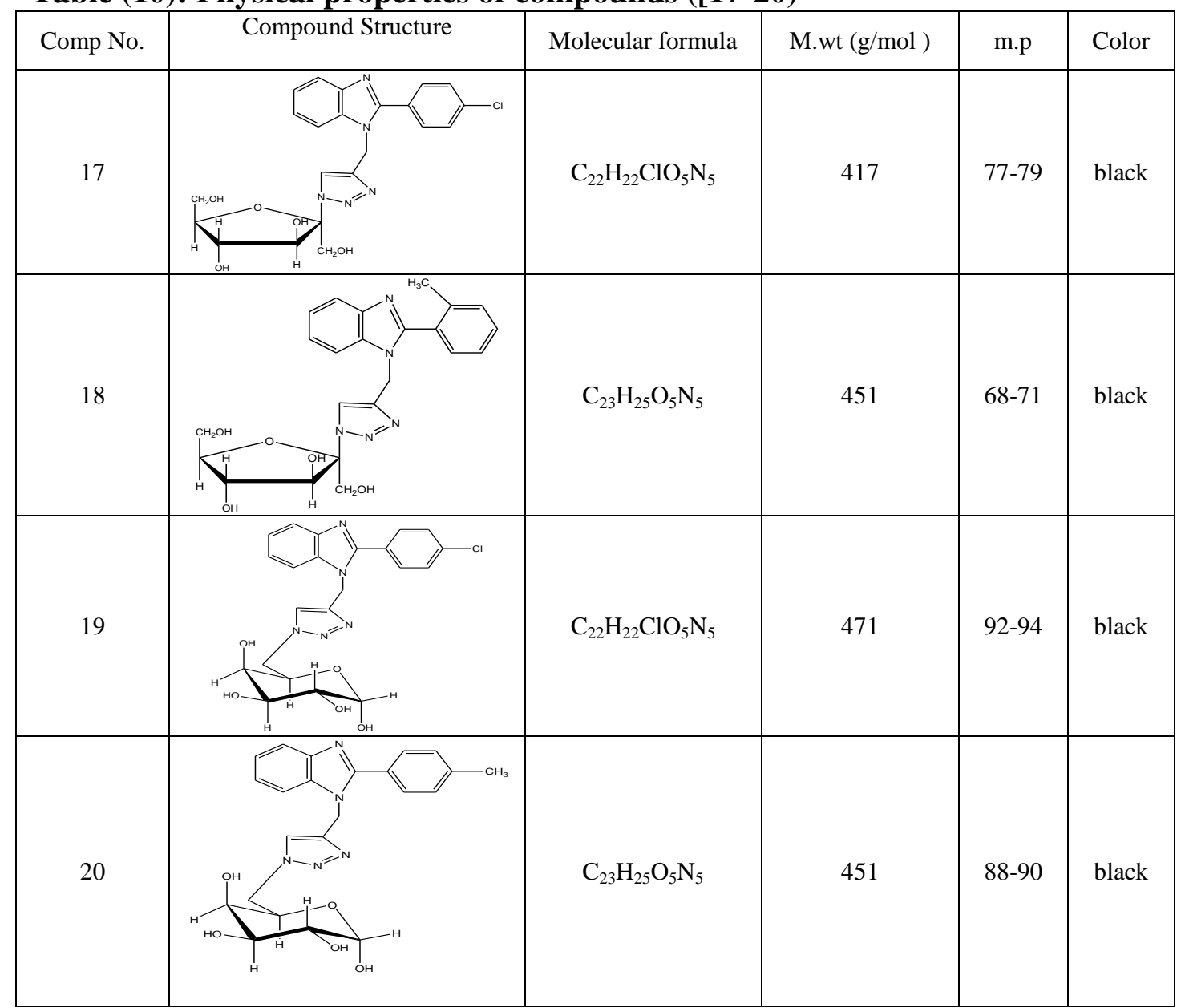

Table(11): FT-IR spectral data for compounds (17-20)

\begin{tabular}{|c|c|c|c|c|c|c|c|}
\hline Comp. & $\boldsymbol{v}(\mathbf{N}=\mathbf{N})$ & $\boldsymbol{v}(\mathbf{C}-\mathbf{H})$ aromatic & $\boldsymbol{v}(\mathbf{C}-\mathbf{H})$ aliph. & $\boldsymbol{v}(\mathbf{C}=\mathbf{C})$ aromatic & $\boldsymbol{v}(\mathbf{C}=\mathbf{N})$ & $\boldsymbol{v}(\mathbf{O}-\mathbf{H})$ & other \\
\hline 17 & 1406 & 3068 & 2960 & 1548 & 1612 & 3400 & \\
\hline 18 & 1403 & 3061 & 2954 & 1588 & 1607 & 3226 & \\
\hline 19 & 1411 & 3060 & 2823 & 1585 & 1602 & 3340 & \\
\hline 20 & 1444 & 3066 & 2955 & 1534 & 1630 & 3630 & \\
\hline
\end{tabular}

The ${ }^{1} \mathrm{H}-\mathrm{NMR}$ spectrum of 20 showed a singlet signal at $1.73 \mathrm{ppm}$ for methyl benzene ring. A sugar protons $\left(\mathrm{H}_{5}{ }_{5}, \mathrm{H}_{6}{ }_{6}, \mathrm{H}^{\prime \prime}{ }_{6}, \mathrm{H}^{\prime}{ }_{4}, \mathrm{H}^{\prime}{ }_{3}, \mathrm{H}_{2}{ }_{2}, \mathrm{H}^{\prime}{ }_{1}\right)$ appeared at
2.5-5 ppm, a signal appeared at $\delta 2.27$ ppm for sugar hydroxyl, while aromatic protons appeared at $\delta 6.8-7.7 \mathrm{ppm}$.

\section{Table(12): ${ }^{1} \mathrm{H}-\mathrm{NMR}$ spectral data for compound (20)}

\begin{tabular}{|l|c|c|}
\hline Comp. No. & $\begin{array}{c}{ }^{1} \mathrm{HNMR} \text { Spectral data }(\delta \mathrm{ppm}) \\
1.73(\mathrm{~s}, 3 \mathrm{H}, \text { methyl); } \\
20.27(\mathrm{~s}, 4 \mathrm{H}, 4 \mathrm{OH}) ; 2.5-5(\mathrm{~m}, 7 \mathrm{H}, \\
\left.\mathrm{H}_{5}^{\prime}, \mathrm{H}_{6}^{\prime}, \mathrm{H}_{6}^{\prime \prime}, \mathrm{H}_{4}^{\prime}, \mathrm{H}_{3}^{\prime}, \mathrm{H}_{2}, \mathrm{H}_{1}^{\prime}\right) ; \\
6.8-7.7\left(\mathrm{~m}, 9 \mathrm{H}, \mathrm{Ar}_{1}-\mathrm{H}_{2} \text { and }\right. \\
\text { triazole proton) }\end{array}$ \\
\hline
\end{tabular}


The ${ }^{13} \mathrm{C}-\mathrm{NMR}$ spectrum of compound (20) showed the appearance of sugar carbons at 68.4-78.6 ppm, aromatic carbons appeared at 119.1-130.1 ppm, while the signal at $160.3 \mathrm{ppm}$ refers to imidazole carbon, a signal at 54.12 refers to methylene group, while carbon for triazole appeared at $130.6 \mathrm{ppm}$ and $151.65 \mathrm{ppm}$.

\section{Table(13): ${ }^{13}$ C-NMR spectral data for compound (20)}

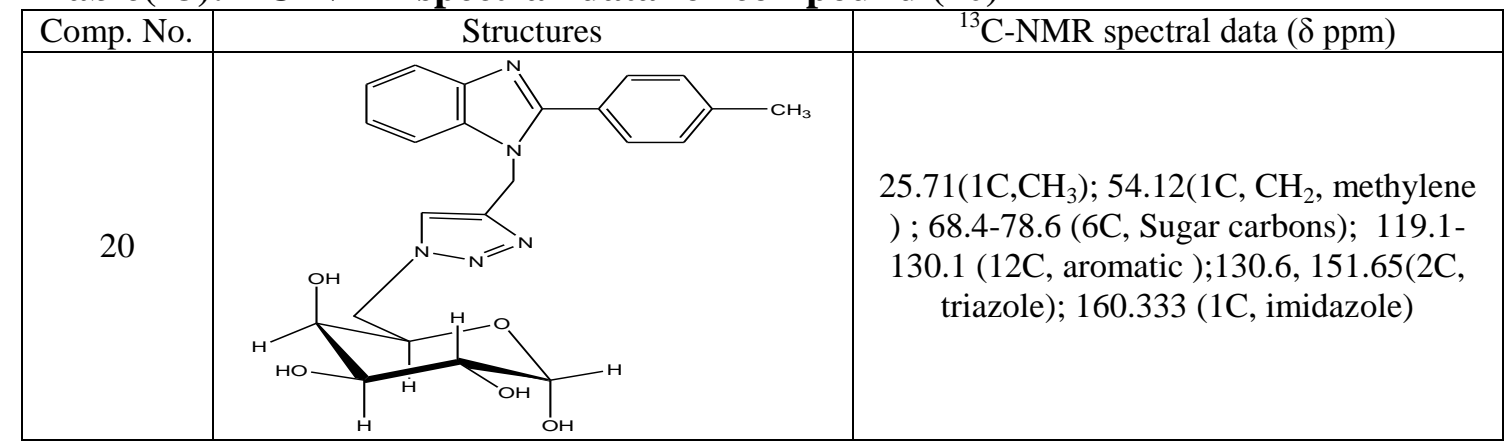

\section{References}

[1]Dogruer, D.S.; Urlu, S.; Onkol, T.; Ozcelik, B. and Sahin, M. F. 2010. Synthesis of some pyridazine derivatives carrying urea, thiourea, and sulfonamide moieties and their antimicrobial activity. Turk. J. Chem., (34.): 57-65.

[2]Horwood, E. 1991. Nucleoside Synthesis Organosilicon Methods. New York.

[3]Bryan, M. Bishop . 2015. Potential and Emerging Treatement Options for Ebola Virus Diseease. Ann. Pharmacother 49(2):196-206

[4]World Health Organization. 2014. WHO Consultation on PotentialEbola Therapies and Vaccines: Background Document for Participants. Geneva, Switzerland: World Health Organization.

[5]Ingle, R.G. and Magar, D.D. 2011. Heterocyclic Chemistry Of Benzimidazoles And Potential Activities Of Derivatives. Int. J. Drug Res. Tech., 1 (1): 26-32

[6]Carla, I.; Nieto, Pilar, C. M. ; Ángeles, G. R. M.; Claramunt; I. A. and José E. 2014. An experimental and theoretical NMR study of NHbenzimidazoles in solution and in the solid state:proton transfer and tautomerism. Beilstein J. Org. Chem.
(10): 1620-1629.

[7] Sreenivasulu, E.; Anees P.; Muiz G.; Javed A. Shaikh and Khursheed A., 2014. Diverse Pharmacological aspects of Benzimidazole Derivatives: A Review. Res. J. Chem. Sci. 4(4): 78-88,

[8]Yadav, L.D.S. and Dayaram, P. 1996. Synthesis and Antiviral Activity of New1， 3， 4, Thiadiazine (4,5) Benzimidazole Derivatives. Indian J. Chem. 35(7B): 748-751.

[9]El-Sayed, A.M. 1997. Synthesis and invitro anti-HIV activity ofcertain 2(1H-Benzimidazol-2-ylamino) pyrimidin- $4(3 \mathrm{H})$-ones and related derivatives. Arch Pharm. (12):59-62.

[10] Reddy, C. V. 1990. Synthesis and anthelminticactivity of methyl [5(6)-(3-oxo-1,4-benzothiazin-7yloxy)benzimidazole]-2carbamates. Indian J. Chem. 29(B):297-299A.

[11] Sawney, S.N. 1990. Snthesis and Anti-Inflammatory Activity of Some2-(5-Aryl-4,5-Dihydro pyrazol3-Yl)-and 2-(2- Amino-6Arylpyrimidin-4-Yl) Benzimidazoles). Indian J. Chem. 29(B):107-112.

[12] Mavrova, A. T.; Anichina K. K.; Vuchev D. I.; Issenov J.A,; Denkova 
P.S.; Kondeva M.S. and Micheva, M.K. 2006. Antihelminthicactivity of some newly synthesized 5(6)-(un) substituted-1H-benzimidazol- 2ylthioacetylpiperazine derivatives. Eur. J. Med. Chem. (41): 1412-1420

[13] Mukesh,S.C. 2010. Synthesis and Biological Evaluation of Some New Benzimidazole Derivatives 4' $-\{5$ Amino-2- [2-SubstitutedPhenylamino) -Phenyl-Methyl]Benzimidazol1yl methyl -Biphenyl2-Carboxylic acid: Non Peptide AngiotensinII Receptor Antagonists. Indian J. Chem. (2):265-277.

[14] Refaat, H. M. 2010. Synthesis and Anticancer Activity of Some Novel 2-Substituted Benzimidazole Derivatives. Eur. J. Med. Chem.
45(7):2949-56.

[15] Jitender, S. 2010. Synthesis, anticonvulsant activity and comparative QSAR study of some novel 1, 2, 5- tri substituted benzimidazole derivatives Acta Pharm sinic (52); 510-521.

[16] Sharma, P. 1999. Synthesis of new 2-(substituted benzothiazolyl carbamoyl) benzimidazoles as potential CNS depressant. Indian J. Chem.(38B):1289-1294

[17] Al-Mouamin Th. M. and Kadhim A. Kh. 2015 Synthesis and Characterization of some new nucleoside analogues from substituted Benzimidazole and evalution of their biological activites, Iraqi J. Science, 56(1C):633-644

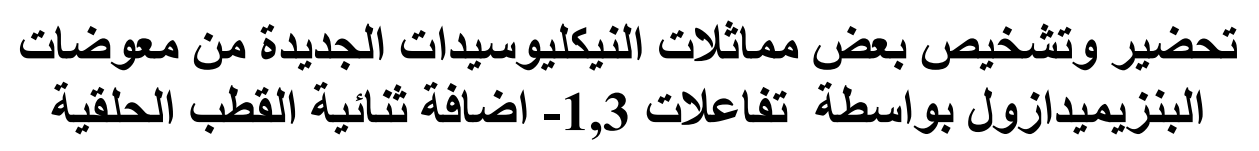

*** أحمد خضير كاظم

$$
\begin{aligned}
& \text { *ثاء مهدي المؤمن* } \\
& \text { "جامعة بغداد /كلية العلوم / قسم الكيمياء/ بغداد/العر اق اق العذاد }
\end{aligned}
$$

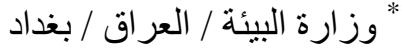

الخلاصة

يحتوي هذا البحث تحضير بعض مماتلات نيكليوسيدات جديدة ابتداءا من مشتقات 2- البنزيميدازول

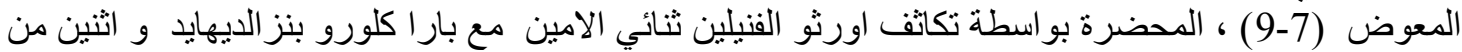

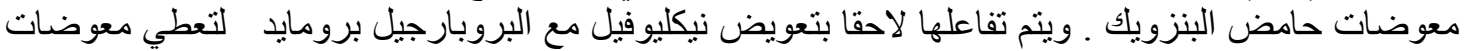

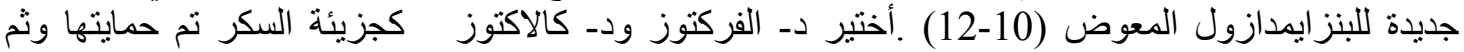

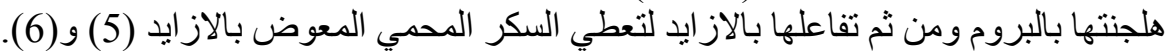

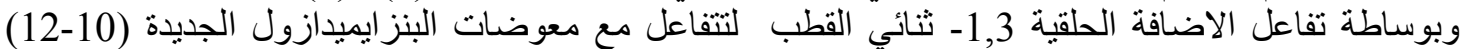
لتعطي نيكليوسيدات محمية (13-16) و التي يتم تحلليها فيما بعد لتعطي الهدف الرئيس ممانتلات نيكليوسيدات

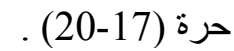
جميع المركبات المحضرة تم تحديدها بأستخدام FT-IR وبعضها بأستخدمها 10-17 ${ }^{13} \mathrm{C}-\mathrm{NMR}$ ب 